\title{
Docking of Potent Anticancer Agents; 4-(Pyrazol-4yl)-Pyrimidine Derivatives as Selective Cyclin-Dependent Kinase 4/6 Inhibitors
}

\author{
Akrimah, Daryono Hadi Tjahyono, and Amir Musadad
}

\begin{abstract}
Cyclin-dependent kinases (CDKs) are regulatory protein kinases which involved in cell cycle control. Many CDK inhibitors have been studied for anticancer potential. Here we conducteda docking studyof 4-(pyrazol-4-yl)-pyrimidine derivatives as CDK1/2 and CDK4/6 inhibitors. Selectivity is an important aspect regarding the anticancer effect. In this computational research, we analyzed the interactionof 4-(pyrazol-4-yl)-pyrimidine derivatives with their receptors, CDK4/6 and CDK2. We compared the docking result of the parent compound, the most selective, and the least selective compound. Docking of the three compounds wasperformed using software Arguslab CDK 4.0.1 to assess the interaction withthereceptors.Three docking parameters were analyzed; Gibbs free energy $(\Delta G)$, atoms and residue of receptor involved in hydrogen bonding, and the bonding length. All three compounds had value of $\Delta G<0$, indicated that the interaction between the ligand and receptor was spontaneous. However, none of these parameters and descriptors values could explain the selectivity order of the three compounds.
\end{abstract}

Index Terms-Anticancer, CDK inhibitor, computational chemistry, docking, pyrazolo pyrimidine derivatives.

\section{INTRODUCTION}

Abnormal proliferation and out of controlcell cycle is the main characteristic of cancer cells. Cyclin-dependent kinase $(\mathrm{CDK})$ is a protein kinase which involved in controlling cell cycle. It regulates transitions of one phase to another. CDKs activity is controlled by several complex mechanisms. CDK activation requires certain cyclin binding and phosphorylation of a conserved threonine by the CDK-activating kinase (CAK) [1]. CDK's important role in cell cycle leads them to become a potential anticancer compounds [2]. Their inhibition mechanism commonly involve a competition with ATP for binding in the kinase ATP-binding site [3]. CDK inhibitors form hydrogen bonding with the certain residue at ATP binding pocket of the CDKs . This bonding is affected by the polarity of the substituents that interact with the ATP binding pocket [4].

Young Shin Cho et.alsynthesized 4-(pyrazol-4-yl)-pyrimidines derivativesas CDK1, 2 and CDK4/6 inhibitors. Results showed that inhibition of CDK4/6 kinase activity stopped the tumor cells progression

Manuscript received June 14, 2013, revised September 18, 2013.

Akrimah is with the Pharmacy Department, Sriwijaya University, South Sumatra, Indonesia (e-mail: akrimah@gmail.com).

Hadi Tjahyono and Amir Musadad are with the School of Pharmacy, Bandung Institute of Technology, West Java, Indonesia. in various in vivo and in vitro models, while CDK1 inhibition leads to apoptosis of all cell systems investigated. It indicates that selective CDK4/6 inhibitors potentially have a larger therapeutic window compared with pan-CDK inhibitors [5]. Selectivity of the CDK-inhibitors isimportant for their anticancer pharmacological activity [3].

Quantitative structure activity relationship(QSAR) is one of the most effective methods in new drug development, since it makes the process more efficient, less expensive and time consuming. It is used particularly in optimizing lead compounds and designing new chemical entities [6].

QSAR study of 4-(pyrazol-4yl)-pyrimidine derivatives and molecular design of CDK1/2 and CDK 4/6 inhibitors as potent anticancer agents were already executed before.This research used several softwares, the modeling and the geometry structures optimization of the 4-(pyrazol-4-yl)-pyrimidine derivatives molecules were done by Gaussian software. Calculation of descriptors value and multiple linear statistical analysis were performed by MOE 2009.10 and SPSS Statistics 17.0, respectively. The results were then validated by LOO (Leave One Out) method to obtain the QSAR equation with the highest $q^{2}$.The QSAR equations are shown in Table I [7].

TABLE I: QSAR EQUATIONS OF CDK2 AND CDK4 INHIBITORS

\begin{tabular}{|c|c|c|}
\hline Activity & QSAR Equation & Statistic Parameters \\
\hline $\begin{array}{c}\text { CDK2 } \\
\text { Inhibition }\end{array}$ & $\begin{array}{l}\log \mathrm{IC}_{50} \mathrm{CDK} 2= \\
1.893( \pm 0.982)-3.359 \times 10^{-5} \\
\left( \pm 4.609 \times 10^{-6}\right) \mathrm{AM} 1 \_\mathrm{E}-0.02438 \\
( \pm 0,007943) \mathrm{ASA}-\mathrm{H}+ \\
1.021( \pm 0.3911) \mathrm{mr}\end{array}$ & $\begin{array}{l}r=0.940 \\
r^{2}=0.884, \\
F=7.7557, q^{2}=0,81142 \\
n=15\end{array}$ \\
\hline $\begin{array}{c}\text { CDK4 } \\
\text { Inhibition }\end{array}$ & $\begin{array}{l}\operatorname{LogIC}_{50} \mathrm{CDK} 4= \\
0.5346( \pm 0.9034)+1.713 \times 10^{-5} \\
\left( \pm 6.652 \times 10^{-6}\right) \text { AM1_E }+0.01391 \\
( \pm 0.006607) \text { ASA_H }-0.2242 \\
( \pm 0,07693) \text { polarizability }\end{array}$ & $\begin{array}{l}r=0.960, \\
r^{2}=0.921, F=13.4045, \\
q^{2}=0.88718 \\
n=16\end{array}$ \\
\hline
\end{tabular}

The substituents at the parent compound which replaced are chlorine $\left(R_{2}\right)$ and isopropyl $\left(R_{1}\right)$ at the pyrazole ring. Substitution at $\mathrm{R}_{1}$ position affects its hydrophobic interaction toward CDKs and substitution at $R_{2}$ can affect its CDK4 inhibition activity [5].

The substituents for new drug design were; $-\mathrm{CH}_{3},-\mathrm{NH}_{2}$, $-\mathrm{F},-\mathrm{Cl},-\mathrm{C}_{3} \mathrm{H}_{7},-\mathrm{N}\left(\mathrm{CH}_{3}\right)_{2},-\mathrm{NO}_{2}$, and $-\mathrm{CF}_{3}$. Modification were performed in combinatorial at $R_{1}$ and $R_{2}$ position of the pyrazole ring, shown in Fig. 1.The predicted $\mathrm{IC}_{50}$ of the new compounds were calculated with the established QSAR equations, the highly selective CDK4 inhibitors indicated by 
the low $\mathrm{IC}_{50}$ for $\mathrm{CDK} 4$ and high $\mathrm{IC}_{50}$ for $\mathrm{CDK} 2$. The highest selective CDK4 inhibitor was parent compound substituted by $\mathrm{CF}_{3}$ at both $R_{1}$ and $R_{2}$, which has the biggest molecular weight of all substituents. The last two selective CDK4 inhibitors were compounds with substituent $\mathrm{CH}_{3}$ and substituent $\mathrm{NH}_{2}$ at both $R_{1}$ and $R_{2}$ position, and its selectivity value were 21 -fold and 18 -fold, respectively [7].<smiles>[R]c1n[nH]c([R2])c1-c1ccnc(Nc2ccc(N3CCNCC3)cn2)n1</smiles>

Fig. 1. Molecular structural schemes of [4-(pyrazol-4-yl)-pyrimidin-2-yl]-(5-piperazin-1-yl-pyridin-2-yl)-amine derivatives.

Docking is a process of placing a molecule into the active site of thetarget macromolecule through noncovalent bonding. It's an important part of structure-based drug design in order to optimize the bound ligand or a series of congenericmolecules [8]. Several methods have been available and reported for validating docking programs [9], [10]. The commonly used method is pose selection, by using a cocrystal structure with aknown inhibitor [11]

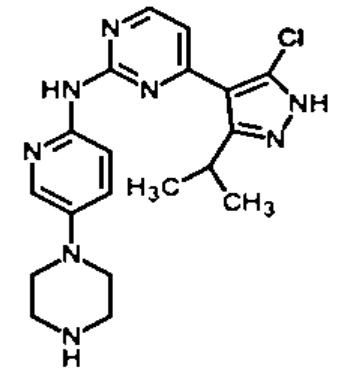

$$
\begin{gathered}
\mathrm{IC}_{50} \mathrm{CDK} 2=1.435 \mu \mathrm{M} \\
\mathrm{IC}_{50} \mathrm{CDK} 4=0.011 \mu \mathrm{M} \\
\text { Selectivity }=130.455
\end{gathered}
$$

(a)
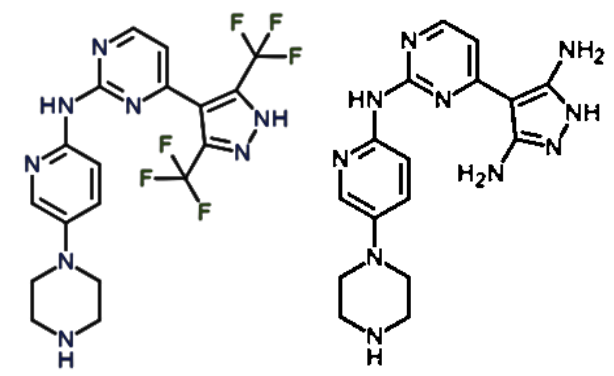

$$
\begin{aligned}
\mathrm{IC}_{50} \mathrm{CDK} 2 & =94.174 \mu \mathrm{M} \\
\mathrm{IC}_{50} \mathrm{CDK} 4 & =0.010 \mu \mathrm{M} \\
\text { Selectivity } & =9035.232
\end{aligned}
$$

(b)

$$
\begin{gathered}
\mathrm{IC}_{50} \mathrm{CDK} 2=1.012 \mu \mathrm{M} \\
\mathrm{IC}_{50} \mathrm{CDK} 4=0.056 \mu \mathrm{M} \\
\text { Selectivity }=18.059
\end{gathered}
$$

(c)
Fig. 2. Molecular structures of ligands. (a)The parent compound [4-(5-chloro-3-isopropyl-1H-pyrazol-4-yl)-pirimidine-2-yl]-(5-piperazin-1yl-piridin-2-yl)-amine, (b) the most selective CDK4/6 inhibitor compound [4-(3,5-ditrifluoromethyl-1H-pyrazol-4-yl)-pyrimidin-2-yl]-(5-piperazin-1yl-pyridin-2-yl)-amine, (c) the least selective CDK4/6 inhibitor compound [4-(3,5-diamine-1H-pyrazol-4-yl)-pyrimidin-2-yl]-(5-piperazin-1-yl-pyridin -2-yl)-amine.
In this computational chemistry research, we conduct docking study on a series of 4-(pyrazol-4-yl)-pyrimidine derivatives towards its receptors, CDK4 and CDK2. We compared the docking result between three compounds; the parent compound (a), the most selective (b) and the least selective (c) compound. The molecular structure of the three compounds and their anticancer activities are shown in Fig. 2.

\section{METHODS}

Structures of the three compounds were optimized by Hartfree-Fock method to verify the most stable conformation with minimum energy. Software used for this optimization was Gaussian 03W. The descriptors values AM1E, ASA_H, $\mathrm{mr}$ and polarizability were calculated by MOE 2009.10.

Docking program used in this study was Arguslab 4.0.1.The molecular structure of $\mathrm{CDK} 2$ protein can be downloaded from the website of protein data bank (PDB), www.rscb.org. The molecular structure of CDK4 was not yet available. However, the structure of the CDK4 and CDK6 is homologous with the amino acid residue sequence similarity of $68 \%$ and $81 \%$ similarity in the ATP binding pocket region [4]. Therefore, the structure of CDK6 was used in the docking process.

The method used for docking validation waspose selection. In this method, a compound with a known conformation and orientation from a cocrystal structure is redock into the target's active site [11]. Natural ligand of the receptor molecule CDK is ATP. At CDK PDB file downloaded, ATP ligand is only found in CDK2. Thus in the validation process, molecule of ATP was redock into CDK2.

The main parameters to be compared of the three compounds were (i) Gibbs free energy, $\Delta \mathrm{G}$, (ii) atoms and residue of receptor involved in hydrogen bonding, and (iii) bonding length.

The CDK ATP binding pocket consists of four regions, the third region (residues 78-90) is the residue involved in the formation of hydrogen bonds with ATP or CDK inhibitor compounds [4]. Therefore, residue number 78 to 90 is a binding site thatused in the process of docking the inhibitor compounds into CDK2 and CDK6 receptor.

\section{RESUlTS AND DISCUSSION}

In docking validation, ATP was redock into CDK2.The rmsd value was $2.77 \AA$ at grid resolution 0.15 . Docking programs arepreferredto predict experimental poses with averagedeviationsfrom 1.5 to $2 \AA$ rmsd [12], [13]. However, this hasbeen an issue for the available docking programs. In some reports, rmsd in range 1.5-3.5 $\AA$ is still acceptable [14], [8].

The docking results of the three compounds to CDK2 and CDK6 are shown in Fig. 3 and Fig. 4. It shows the interaction position between the ligand and the receptor. If there was no interaction, the ligand and the receptor would be far from each other.The numbers in red are the bonding length, it can be seen more clearly in the tables below. 


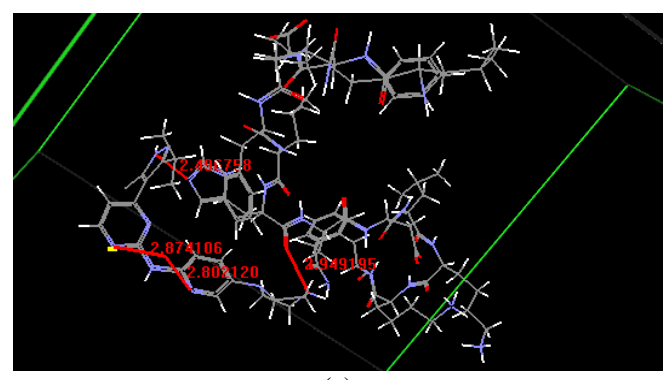

(a)

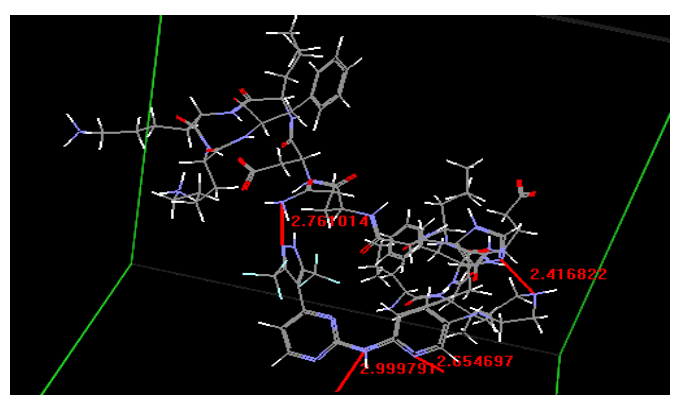

(b)

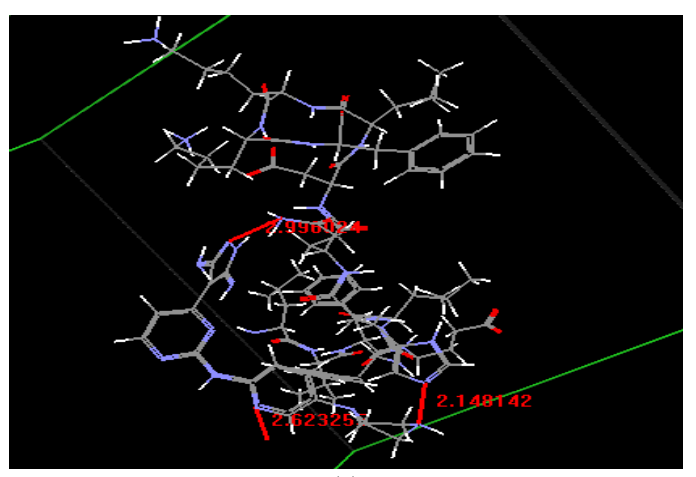

(c)

Fig. 3. Docking result of ATP binding site at CDK2into :(a) parent compound, (b)the most selective compound, (c) the least selectivecompound.

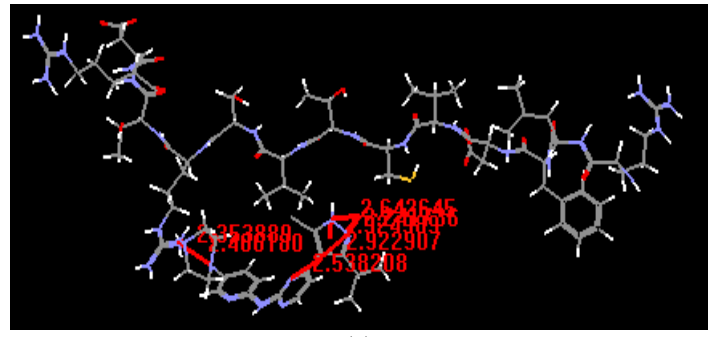

(a)

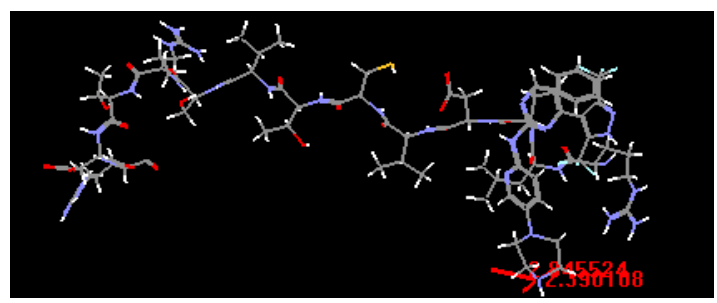

(b)

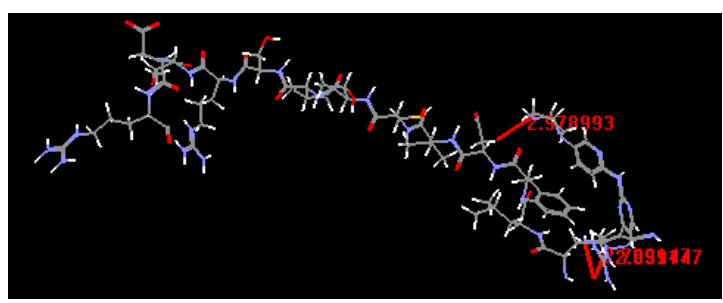

(c)

Fig. 4. Docking result of ATP binding site at CDK6 into (a) parent compound, (b) the most selective compound, (c) the leastselective compound.
Ligand docking compound parameters for each receptor are shown in Table II and Table III. Free energy change $(\Delta G)$ is a parameter that indicates the affinity and stability of the interaction between the ligand to the receptor. $\Delta G$ value $<0$ indicates the interaction takes place spontaneously, and the value of $\Delta G>0$ indicates no interaction can take place spontaneously [15].

TABLE II: DOCKING PARAMETERS FOR LIGAND-CDK2 INTERACTION

\begin{tabular}{|c|c|c|c|c|}
\hline \multirow[t]{2}{*}{ Ligand } & \multirow[t]{2}{*}{$\begin{array}{c}\Delta G \\
(\mathrm{kCal} / \mathrm{mol})\end{array}$} & \multicolumn{2}{|c|}{$\begin{array}{c}\text { Atoms and residue } \\
\text { of receptor involved } \\
\text { in hydrogen } \\
\text { bonding }\end{array}$} & \multirow[t]{2}{*}{$\begin{array}{l}\text { Bonding } \\
\text { length } \\
\text { (̊) }\end{array}$} \\
\hline & & Atom & Residue & \\
\hline \multirow{4}{*}{$\begin{array}{c}\text { Parent } \\
\text { Compound }\end{array}$} & \multirow{4}{*}{-8.1046} & $\mathrm{~N}$ & 84 HIS & 2.4967 \\
\hline & & $\mathrm{N}$ & 20 LYS & 2.8021 \\
\hline & & $\mathrm{N}$ & $20 \mathrm{LYS}$ & 2.8741 \\
\hline & & $\mathrm{O}$ & 84 HIS & 2.9491 \\
\hline \multirow{4}{*}{$\begin{array}{l}\text { The most } \\
\text { selective } \\
\text { compound }\end{array}$} & \multirow{4}{*}{-7.5512} & $\mathrm{~N}$ & 84 HIS & 2.4168 \\
\hline & & $\mathrm{N}$ & 20 LYS & 2.6547 \\
\hline & & $\mathrm{N}$ & 85 GLN & 2.7610 \\
\hline & & $\mathrm{O}$ & 8 GLN & 2.9998 \\
\hline \multirow{3}{*}{$\begin{array}{l}\text { The least } \\
\text { selective } \\
\text { compound }\end{array}$} & \multirow{3}{*}{-7.4101} & $\mathrm{~N}$ & 84 HIS & 2.6232 \\
\hline & & $\mathrm{N}$ & $20 \mathrm{LYS}$ & 2.1481 \\
\hline & & $\mathrm{N}$ & 85 GLN & 2.9960 \\
\hline
\end{tabular}

TABLE III: DOCKING PARAMETERS FOR LIGAND-CDK6 INTERACTION

\begin{tabular}{|c|c|c|c|c|}
\hline \multirow[t]{2}{*}{ Ligand } & \multirow[t]{2}{*}{$\begin{array}{c}\Delta G \\
(\mathrm{kCal} / \mathrm{mol})\end{array}$} & \multicolumn{2}{|c|}{$\begin{array}{l}\text { Atoms and residue } \\
\text { of receptor involved } \\
\text { in hydrogen } \\
\text { bonding }\end{array}$} & \multirow[t]{2}{*}{$\begin{array}{l}\text { Bonding } \\
\text { length } \\
(\AA)\end{array}$} \\
\hline & & Atom & Residue & \\
\hline \multirow{7}{*}{$\begin{array}{c}\text { Parent } \\
\text { compound }\end{array}$} & \multirow{7}{*}{-7.8877} & $\mathrm{O}$ & 95 THR & 2.6426 \\
\hline & & $\mathrm{O}$ & 10 ASP & 2.9245 \\
\hline & & $\mathrm{O}$ & 95 THR & 2.4174 \\
\hline & & $\mathrm{N}$ & $44 \mathrm{ARG}$ & 2.9220 \\
\hline & & $\mathrm{N}$ & $44 \mathrm{ARG}$ & 2.5382 \\
\hline & & $\mathrm{N}$ & $87 \mathrm{ARG}$ & 2.4062 \\
\hline & & $\mathrm{N}$ & $87 \mathrm{ARG}$ & 2.3539 \\
\hline \multirow{2}{*}{$\begin{array}{l}\text { The most } \\
\text { selective } \\
\text { compound }\end{array}$} & \multirow{2}{*}{-6.5808} & $\mathrm{~N}$ & 583ARG & 2.3901 \\
\hline & & $\mathrm{N}$ & 583ARG & 2.8455 \\
\hline \multirow{3}{*}{$\begin{array}{l}\text { The least } \\
\text { selective } \\
\text { compound }\end{array}$} & \multirow{3}{*}{-6.6075} & $\mathrm{O}$ & $99 \mathrm{GLU}$ & 2.9991 \\
\hline & & $\mathrm{O}$ & 99 GLU & 2.7891 \\
\hline & & $\mathrm{O}$ & 13 TYR & 2.9790 \\
\hline
\end{tabular}

The docking result of receptors CDK2 and CDK6 shows that all three compounds had value of $\Delta G<0$ which indicates that the interaction between the ligand and receptor was spontaneous. There is no particular order of these parameters that can be associated with their selectivity order.

However, there is a distinction of the residue of the receptor CDK2 that involved in hydrogen bonding. Three of them formed hydrogen bonding to 84 HIS and 20 LYS residue with different length. The order of the bonding length at 84 HIS residue reflects the selectivity of the compounds, the more selective compound has the shorter bonding length.However, since there is no other supporting data, the exact correlation of this parameter can not be conluded.

Both QSAR equations for CDK2 and CDK4/6includedAM1_E (total energy), and ASA_H (hydrophobic surface area) descriptors. The distinction between the two QSAR equations was that CDK2 equation contained descriptor $\mathrm{mr}$, while $\mathrm{CDK} 4$ contained polarizability.

Therefore, it was predicted that the molar refractivity and 
polarizability distinction in both equations indicated that the steric and polarizability parameter could possibly determine the selectivity of CDK2 and CDK4/6 inhibitors [7].Molar refractivity is a measure of the steric bulk of a molecule. The value is proportional to themolecular weight of the compound. While polarizability indicates atomic or molecular charge distribution of a molecule [6].

The descriptors values of the three compounds are shown in Table IV.

TABLE IV: DESCRIPTOR VALUE OF THE LIGANDS AND THE ANTICANCER

\begin{tabular}{|c|c|c|c|c|c|}
\hline \multicolumn{6}{|c|}{ ACTIVITY. } \\
\hline \multirow{2}{*}{ Ligand } & \multirow{2}{*}{ Activity } & \multicolumn{4}{|c|}{ Descriptors } \\
\hline & & AM1_E & ASA_H & $\mathrm{Mr}$ & pol. \\
\hline $\begin{array}{c}\text { Parent } \\
\text { compound }\end{array}$ & $\begin{array}{c}\mathrm{IC}_{50} \mathrm{CDK} 2: \\
1.435 \mu \mathrm{M} \\
\mathrm{IC}_{50} \mathrm{CDK} 4: \\
0.011 \mu \mathrm{M} \\
\text { Selectivity: } \\
130.455\end{array}$ & -110124.5 & 669.156 & 10.797 & 42.84 \\
\hline $\begin{array}{l}\text { The most } \\
\text { selective } \\
\text { compound }\end{array}$ & $\begin{array}{c}\mathrm{IC}_{50} \text { CDK2: } \\
94.174 \mu \mathrm{M} \\
\mathrm{IC}_{50} \mathrm{CDK} 4: \\
0.010 \mu \mathrm{M} \\
\text { Selectivity: } \\
9035.232\end{array}$ & -163476.45 & 641.294 & 10.009 & 38.53 \\
\hline $\begin{array}{l}\text { The least } \\
\text { selective } \\
\text { compound }\end{array}$ & $\begin{array}{c}\mathrm{IC}_{50} \mathrm{CDK} 2: \\
1.012 \mu \mathrm{M} \\
\mathrm{IC}_{50} \mathrm{CDK} 4: \\
0.056 \mu \mathrm{M} \\
\text { Selectivity: } \\
18.059\end{array}$ & -101238.65 & 610.426 & 9.392 & 38.11 \\
\hline
\end{tabular}

Since there was no docking parameters and descriptor value can explain the selectivity order of the three compounds, this study is expected to be verified with another docking software in another experiment.

\section{REFERENCES}

[1] D. O. Morgan, "Principles of CDK Regulation," Nature, vol. 374, pp. 131-134, March 1995.

[2] K. R Webster, "Therapeutic Potential of Targeting the Cell Cycle," Chem. Res. Toxicol., vol. 13, no. 10, pp. 940-942, 2000.

[3] M. Knockaert, P. Greengard, and L. Meijer, "Pharmacological Inhibitors of Cyclin-dependent kinases," Tren. in Pharm. Sci., vol. 23 no. 9, pp. 417-424. Sept. 2002.
[4] J. Sridhar, N. Akula, and N. Pattabiraman, "Selectivity and Potency of Cyclin-dependent Kinase Inhibitors," AAPS J., vol. 8, no. 1, pp. 204-221, March 2006

[5] Y. S. Cho, M. Borland, C. Brain, C. H. T. Chen, H. Cheng, R. Chopra K. Chung, J. Groarke, G. He, Y. Hou, S. Kim, S. Kovats, Y. Lu, M O'Reilly, J. Shen, T. Smith, G. Trakshel, M. Vogtle, M. Xu, and M. Je Sung, "4-(Pyrazol-4-yl)-pyrimidines as Selective Inhibitors of Cyclin-Dependent Kinase 4/6," J. Med. Chem., vol. 53, no. 22, pp 7938-7957, Jan. 2010

[6] H. Kubinyi, Hansch Analysis and Related Approches, Weinhem, VCH, 1993, pp. 95-96.

[7] Akrimah, D. H Tjahjono, and A. Musadad, "Quantitative Structure-Activity Relationship Study of 4-(pyrazol-4yl)-pyrimidine Derivatives and Molecular Design of Selective Cyclin-Dependent Kinase 4/6 Inhibitors as Potent Anticancer Agents,” M.S thesis, School of Pharmacy, Bandung Institute of Technology, Indonesia, 2012.

[8] M. Kontoyianni, L. Clellan, and G. S. Sokol, "Evaluation of Docking Performance: Comparative Data on Docking Algorithms," J. Med. Chem., vol. 47, no. 3, pp. 558-565, 2004.

[9] A. N. Jain, "Bias, reporting, and sharing: computational evaluations of docking methods," J. Comput.-Aided Mol. vol. 22, pp. 201-212, Des. 2008.

[10] J. C. Cole, C. W. Murray, J. W. Nissink, and R. D. Taylor, “Comparing protein-ligand docking programs is difficult," Proteins, vol. 60, pp. 325-332, 2005.

[11] K. E. Hevener, W. Zhao, D. M. Ball, K. Babaoglu, J. Qi, S.W. White, and R. E. Lee, "Validation of Molecular Docking Programs for Virtual Screening against Dihydropteroate Synthase," J. Chem. Inf. Model., vol. 49, no. 2, pp. 444-460, 2009.

[12] C. Bissantz, G. Folkers, and D. Rognan, "Protein-based virtualscreening of chemical databases. Evaluation of differentdocking/scoring combinations," J. Med. Chem, vol. 43, pp. 4759-4767, 2000.

[13] B. Kramer, M. Rarey, and T. Lengauer, "Evaluation of the FlexXincremental construction algorithm for protein-ligand docking," Proteins, vol. 37, pp. 228-241, 1999.

[14] G. Jones, P. Willett, R. C. Glen, A. R. Leach, and R. Taylor, "Development and validation of a genetic algorithm to flexibledocking," J. Mol. Biol., vol. 267, pp. 727-748, April, 1997.

[15] A. L. Ode, R. E. Kartasasmita, and D. H. Tjahjono, "QSAR Study of 2-Aminothieno [2, 3-d] pyrimidine Derivatives as Hsp90 Inhibitor,' M.S thesis, School of Pharmacy, Bandung Institute of Technology, Indonesia, 2010.

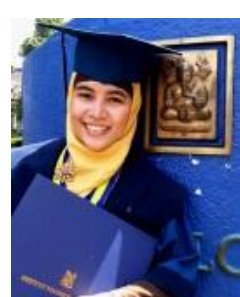

Akrimah was born in Pekanbaru, $4^{\text {th }}$ July 1985 Graduated from School of Pharmacy, Bandung Institute of Technology, West Java, Indonesia, major in pharmacy technology for bachelor degree (2007) and medicinal chemistry for master degree (2012). She has been a lecturer in Pharmacy Department Sriwijaya University, South Sumatra, Indonesia, since May 2012. Before, she was an executive editor at local doctors magazine, Micro Plus, in Palembang, South Sumatra, Indonesia (2008-2010). 